\title{
Tonsillopharyngitis not Responding to Antibiotic Treatment
}

\author{
Antibiyotik Tedavisine Yanıt Vermeyen Tonsillofarenjit
}

Ergin Çiftçi'(iD), Tuğba Erat ${ }^{1}(\mathrm{i}$ )

${ }^{1}$ Division of Pediatric Infectious Diseases, Department of Pediatrics, Ankara University School of Medicine, Ankara, Turkey

Cite this article as: Çiftçi E, Erat T. Tonsillopharyngitis not responding to antibiotic treatment. J Pediatr Inf 2020;14(3):e148-e149.

A four-year-old male patient was brought with complaints of fever and sore throat. It was learned that the patient had suffered fever and sore throat 5 days ago. Amoxicillin-clavulanate had been given to the patient with the diagnosis of tonsillopharyngitis, but he did not benefit from the treatment. The patient's temperature was $38.7^{\circ} \mathrm{C}$, he had exudative tonsillitis and cervical lymph adenopathies. His liver and spleen were found enlarged. Patient's WBC was $24300 / \mathrm{mm}^{3}$ with $22 \%$ atypical lymphocytes. Infectious mononucleosis due to Epstein Barr virus (EBV) was considered in the patient. Antibiotic treatment was discontinued; $1 \mathrm{mg} / \mathrm{kg}$ prednisolone was given due to stridor. EBV IgM and IgG were positive. During the follow-up, the patient recovered without any problems.

Most children in countries with low socioeconomic status become infected with EBV in early childhood. The disease is often confused with streptococcal tonsillopharyngitis due to exudative tonsillitis and lymphadenopathy in the anterior and posterior cervical chain and submandibular area. However, lymphadenopathy is commonly generalized; splenomegaly and hepatomegaly are also accompanied. The presence of atypical lymphocytes (Downey cells) in the peripheral blood smear supports the diagnosis. In the acute phase of infectious mononucleosis, EBVVCA IgM, EBVVCA lgG and EA IgG become positive. Since infectious mononucleosis is a self-limiting disease, treatment is supportive. Corticosteroid therapy is restricted to some conditions such as tonsil hypertrophy that cause airway obstruction.

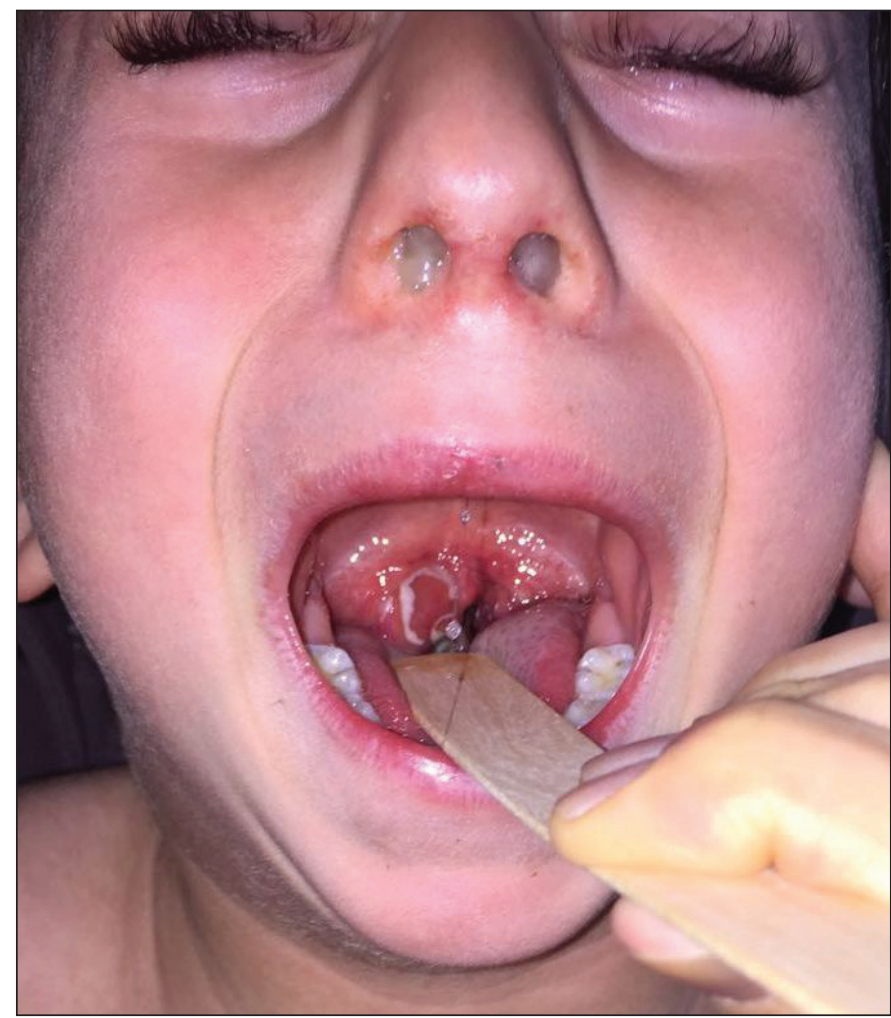

Figure 1. Exudative tonsillitis.

\footnotetext{
Correspondence Address/Yazışma Adresi Ergin Çiftçi

Ankara Üniversitesi Tıp Fakültesi,

Çocuk Sağlığı ve Hastalıkları Anabilim Dalı,

Çocuk Enfeksiyon Hastalıkları Bilim Dalı,

Ankara-Türkiye

E-mail: erginciftci@gmail.com
}

Received: 07.09.2020 


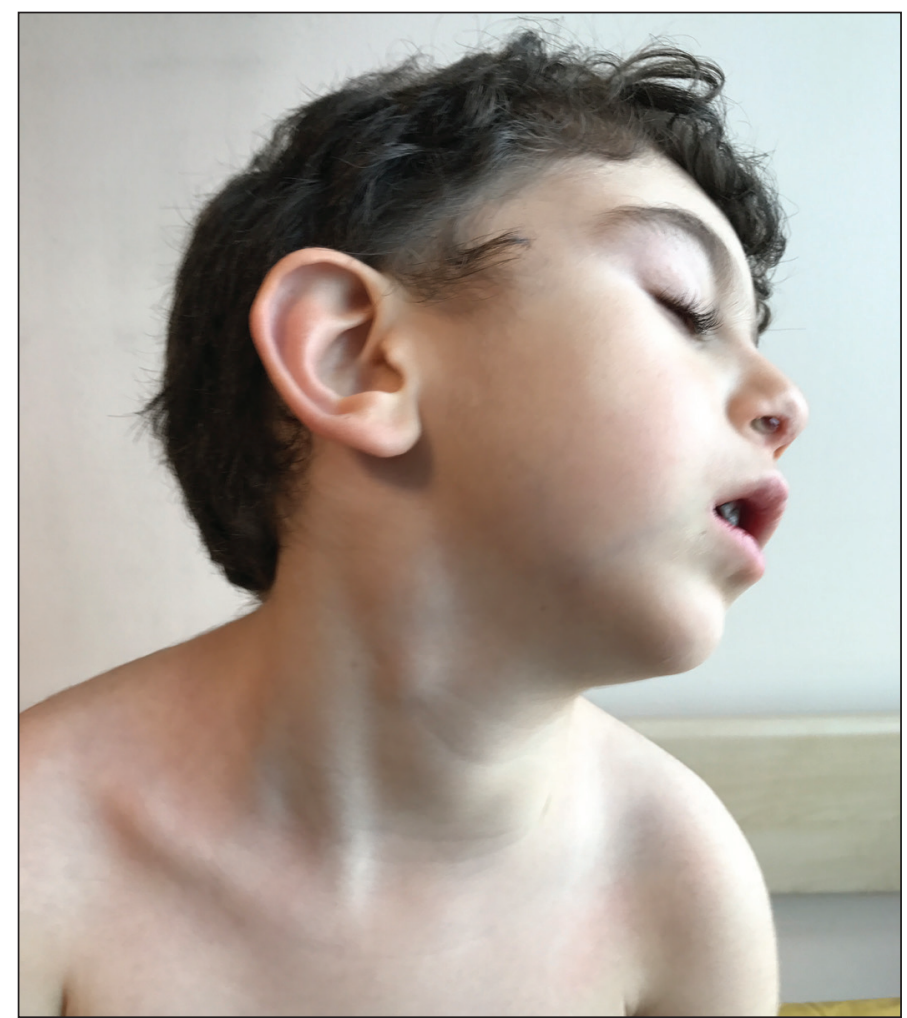

Figure 2. Cervical lymphadenopathies.

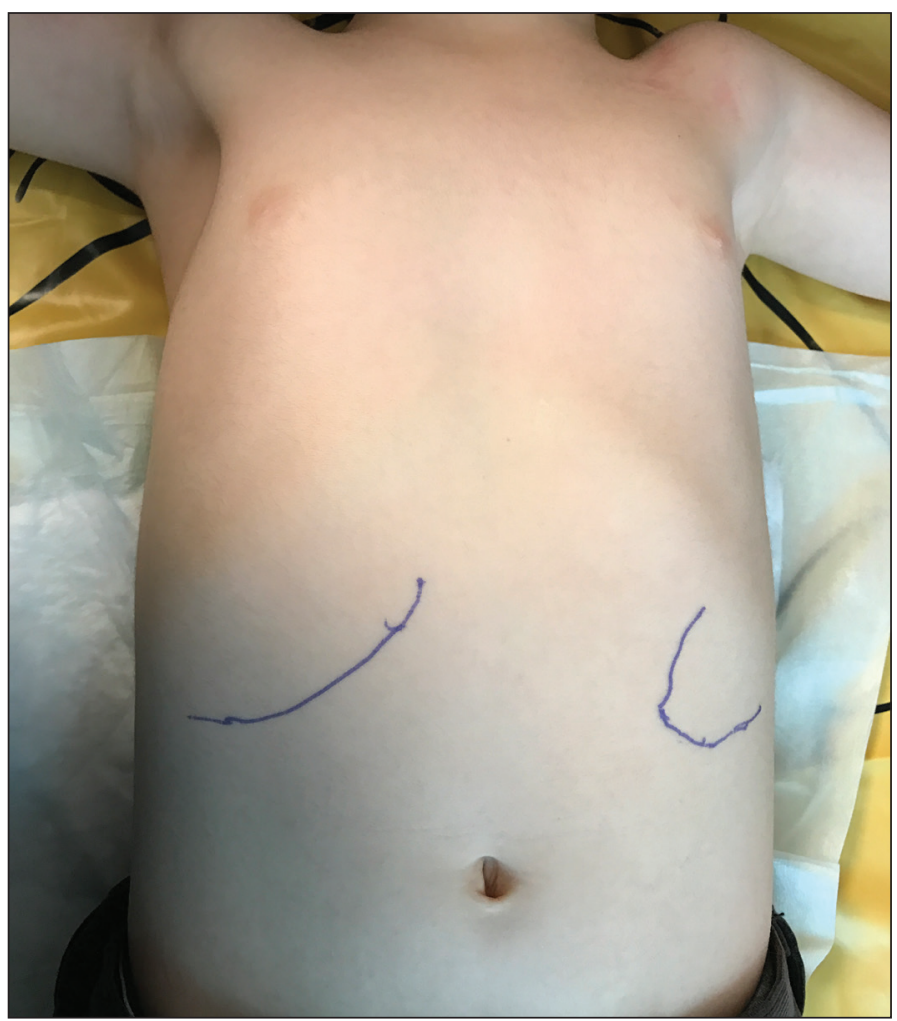

Figure 3. Hepatosplenomegaly.

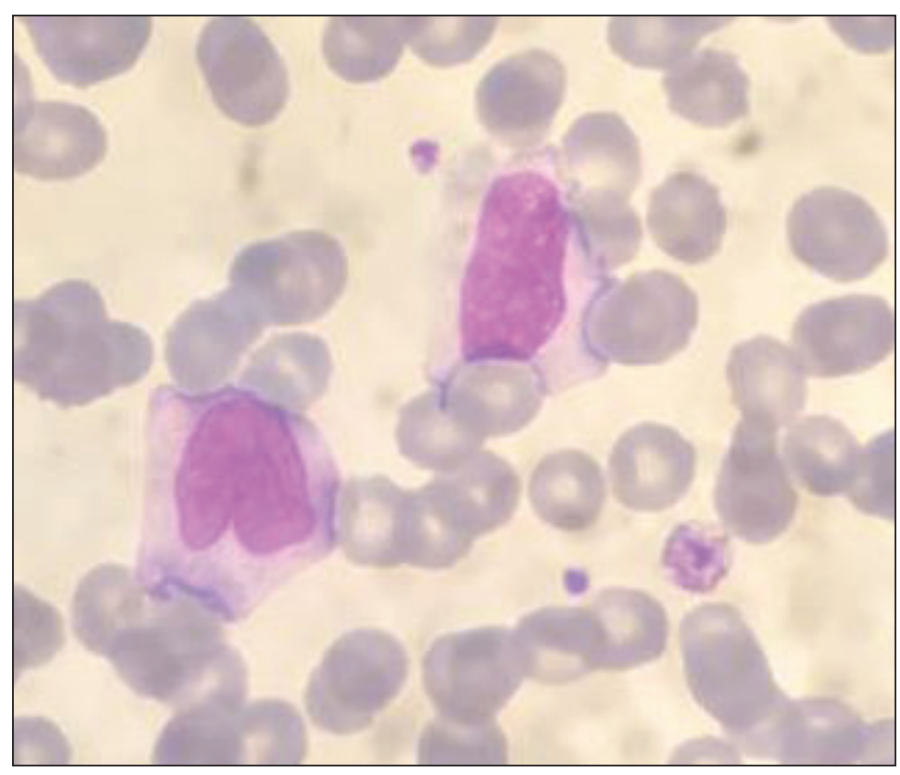

Figure 4. Atypical lymphocytes (Downey cells) on peripheral blood smear. 